\title{
KAJIAN ZONASI KAWASAN CAGAR BUDAYA DI KECAMATAN SIAK KABUPATEN SIAK
}

\author{
Mira Hafizhah T \\ Staff Pengajar Jurusan Teknik PWK, Universitas Islam Riau \\ Email : mirahafizhah@eng.uir.ac.id \\ Diterima (received): 03 Januari 2018 \\ Disetujui (accepted): 15 Maret 2018
}

\begin{abstract}
ABSTRAK
Kecamatan Siak memiliki banyak peninggalan sejarah yang berpotensi untuk menjadi destinasi wisata cagar budaya. Jika potensi ini dikelola dengan baik akan mendatangkan manfaat bagi pembangunan. Namun cagar budaya di Kecamatan Siak belum memiliki zonasi yang berfungsi melindungi cagar budaya dan sebagai instrumen pengendali pembangunan di sekitar cagar budaya. Penelitian ini bertujuan untuk a). Mengidentifikasi cagar budaya di Kecamatan Siak b). Menentukan batas deliniasi kawasan zona inti, zona pendukung dan zona penyangga cagar budaya c). Merumuskan strategi pengembangan cagar budaya di Kecamatan Siak dimasa yang akan datang. Penelitian ini menggunakan metode analisis deskriptif kualitatif. Teknik analisis yang digunakan dalam mengidentifikasi cagar budaya di Kecamatan Siak berdasarkan Undang-Undang Nomor 11 Tahun 2010 tentang Cagar Budaya dan pendapat ahli. Berdasarkan data arkeologi, survei lapangan dan wawancara stakeholder untuk melakukan analisis deliniasi zona inti, pendukung dan penyangga cagar budaya. Hasil penelitian ini menemukan bahwa terdapat delapan situs cagar budaya yang sesuai kriteria di Kecamatan Siak. Dari zonasi kawasan cagar budaya di peroleh dua zona inti, dua zona pendukung dan dua zona penyangga yang terdiri dari zona Komplek Istana Siak dan zona Kelenteng Hok Sing Kong.
\end{abstract}

Kata Kunci : zonasi, budaya, sejarah

\section{A. PENDAHULUAN}

Berdasarkan amanat Undang-Undang Nomor 11 Tahun 2010 tentang Cagar Budaya bahwa cagar budaya merupakan kekayaan budaya bangsa sebagai wujud pemikiran dan perilaku kehidupan manusia yang penting artinya bagi pemahaman dan perkembangan sejarah ilmu pengetahuan, dan kebudayaan dalam kehidupan bermasyarakat, berbangsa, dan bernegara. Benda cagar budaya dapat berupa benda alam atau benda buatan manusia yang dimanfaatkan oleh manusia, serta sisa-sisa biota yang dapat dihubungkan dengan kegiatan manusia dan dapat dihubungkan dengan sejarah manusia. Bersifat bergerak atau tidak bergerak merupakan kesatuan atau keompok, sehingga perlu dilestarikan dan dikelola secara tepat melalui upaya perlindungan, pengembangan, dan pemanfaatan dalam rangka memajukan kebudayaan nasional untuk sebesar-besarnya kemakmuran rakyat.

Menurut Undang-Undang Nomor 11 Tahun 2010 tentang Cagar Budaya, perlindungan adalah upaya mencegah dan menanggulangi dari kerusakan,

Available online : http://journal.uin-alauddin.ac.id/index.php/planomadani 
kehancuran, atau kemusnahan dengan cara membuat zonasi cagar budaya dalam rangka untuk melindungi cagar budaya dan sebagai instrumen pengendali pembangunan di sekitar cagar budaya dan meminimalkan penggunaan lahan yang tidak sesuai.

Menurut Yusuf et al (1992) kekayaan budaya yang dimiliki Kabupaten Siak cukup banyak diantaranya peninggalan sejarah seperti Istana Asserayah Hasimiah, Balairung Sari atau Balai Kerapatan Tinggi, Masjid Raya Siak Syahbudin (Masjid Kerajaan), Tanah Lapang (Alun-alun), Rumah Tahanan Kerajaan, Makam Sultan Syarif Kasim II dan Permaisuri, Latifah School, Madrasa Nisa (Sekolah Agama Putri), Madrasah Taufiqiyah (Sekolah Madrasah Putra), Gedung Mesiu (Gedung Obat Bedil), Gedung Senjata, Makam Koto Tinggi (Tempat Makam Sultan Hasyim), Asrama Polisi Kerajaan Siak, Kantor dan Pelabuhan LLSDF, Kantor Imigrasi, Pemancar TVRI, PLN, kelenteng dan gereja tua serta pasar lama. Pada Kecamatan Mempura terdapat Tangsi Belanda, Rumah Controleur, Rumah Landrat, Rumah Datuk Pesisir dan Makam Sultan Abdul Jalil Rahmad Syah. Kecamtan Koto Gasib terdapat Makam Putri Kaca Mayang, dan di Kecamatan Bunga Raya terdapat Makam Raja Kecil Buantan. Pemerintah Kabupaten Siak mengusulkan Kecamatan Siak dan Kecamatan Mempura sebagai Kota Pusaka Dunia dengan peninggalan cagar budaya yang dimilikinya, namun dua kawasan cagar budaya ini belum memiliki zonasi yang berfungsi untuk melindungi cagar budaya. Berkaitan dengan hal ini penelitian tentang zonasi cagar budaya dilakukan di Kecamatan Siak.

\section{B. TINJAUAN PUSTAKA}

Menurut Undang-Undang Nomor 11 Tahun 2010 tentang Cagar Budaya bersifat kebendaan berupa benda cagar budaya, bangunan cagar budaya, struktur cagar budaya, situs cagar budaya, dan kawasan cagar budaya di darat dan/atau di air yang perlu dilestarikan keberadaanya karena memiliki nilai penting bagi sejarah, ilmu pengetahuan, pendidikan, agama, dan/atau kebudayaan melalui proses penetapan, kriteria cagar budaya menurut Undang-Undang Nomor 11 Tahun 2010 adalah sebagai berikut:

Tabel 1. Kriteria cagar budaya

Kriteria Cagara Budaya

\begin{tabular}{|c|c|}
\hline Undang-Undang Nomor 10 Tahun 2010 & Menurut Dubos (2001) \\
\hline $\begin{array}{l}\text { Benda, Bangunan dan Struktur } \\
\text { a. Berusia } 50 \text { (lima puluh) tahun atau lebih } \\
\text { b. Mewakili masa gaya paling singkat } 50 \\
\text { (lima puluh) tahun } \\
\text { c. Memiliki arti khusus bagi sejarah, ilmu } \\
\text { pengetahuan, pendidikan, agama, } \\
\text { dan/atau kebudayaan } \\
\text { d. Memiliki nilai budaya bagi penguatan } \\
\text { keperibadian bangsa. }\end{array}$ & 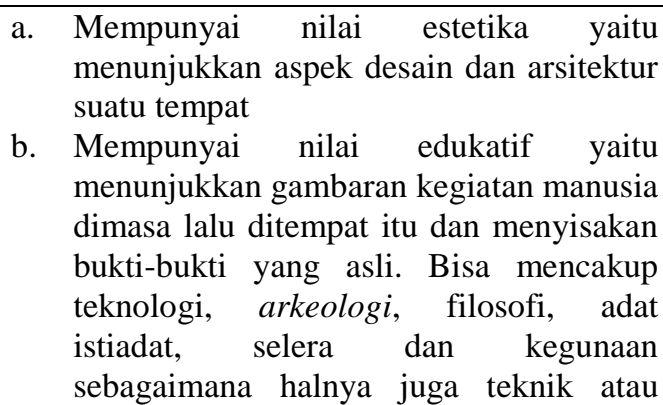 \\
\hline
\end{tabular}


Mira Hafizhah T, Kajian Zonasi Kawasan Cagar Budaya di Kecamatan Siak Kabupaten Siak

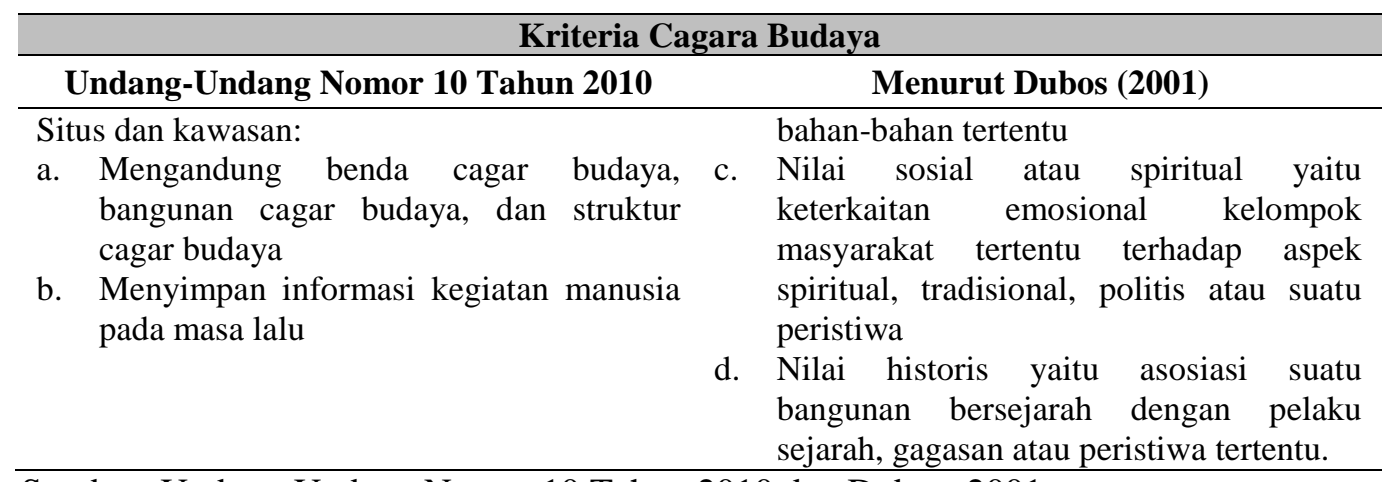

Sumber: Undang-Undang Nomor 10 Tahun 2010 dan Dubos, 2001

Menurut Direktorat Pelestarian Cagar Budaya dan Permusiuman, Direktorat Jendral Kebudayaan Indonesia (2016), ada beberapa hal yang harus menjadi prinsip pemanfaatan, yaitu:

1. Pemanfaatan cagar budaya dilaksanakan sesuai dengan aspek pelestarian dan tidak mengurangi nilai cagar budaya

2. Pemanfaatan cagar budaya mengutamakan peningkatan kesejahteraan masyarakat

3. Pemanfaatan cagar budaya harus menjaga ketertiban, keamanan dan kehidupan masyarakat setempat

4. Pemanfaatan cagar budaya selaras dengan konservasi (perjanjian internasional) bagi warisan budaya dunia dan peraturan perundangan tentang cagar budaya dan peraturan lainnya

5. Pemanfaatan cagar budaya menghormati hukum adat kepercayaan, dan adat istiadat serta norma-norma masyarakat.

Zonasi (zoning) dapat diartikan sebagai upaya untuk menentukan wilayah situs atau wilayah cagar budaya dan lingkungannya beserta batas-batasnya dan mengatur peruntukannya masing-masing untuk kepentingan perlindungan dalam upaya pelestariannya dalam pengertian yang lebih luas, zonasi dilakukan sebagai antisipasi terhadap berbagai kegiatan lain yang tidak sejalan dengan kepentingan pelestarian. Pengaturan wilayah situs dan lingkungannya yang telah ditetapkan merupakan usaha mengendalikan berbagai kegiatan yang dapat mengancam kelestarian situs dan kawasannya (Said, 2013). Menurut Direktorat Pelestarian Cagar Budaya dan Permusiuman, Direktorat Jendral Kebudayaan Indonesia (2016) Secara konsep dalam penentuan zonasi diatas dapat diketahui sebagi berikut:

1. Zona Inti

a. Mutlak untuk mempertahankan keaslian cagar budaya

b. Tidak boleh merusak atau mencemari cagar budaya maupun nilainya

c. Tidak boleh mengubah fungsi kecuali tetap mempertahankan prinsip pelestarian cagar budaya

d. Tidak boleh untuk kepentingan komersil kecuali memenuhi kepatutan 
Mira Hafizhah T, Kajian Zonasi Kawasan Cagar Budaya di Kecamatan Siak Kabupaten Siak

e. Tidak boleh mendirikan bangunan baru atau fasilitas lain kecuali taman, fasilitas pelindung dan fasilitas pengamanan

f. Tidak boleh mendirikan ruang kegiatan yang bertentangan dengan sifat kesakralan.

2. Zona Pendukung

Dapat dipergunakan untuk tempat fasilitas umum dan dapat dipergunakan untuk kawasan permukiman dan fasilitas pendukung/ untuk kepentingan komersil dengan mempertahankan nilai lingkungan budaya.

3. Zona Penyangga

Pemanfaatan zona penyangga diperuntukan bagi penempatan sarana dan prasarana penunjang, kegiatan komersial dan rekreasi umum, dengan memperhatikan luasannya.

Perlindungan non fisik: (regulasi) SK. Penetapan

Cagar Budaya pembuatan PERDA tentang Cagar Budaya, dll.

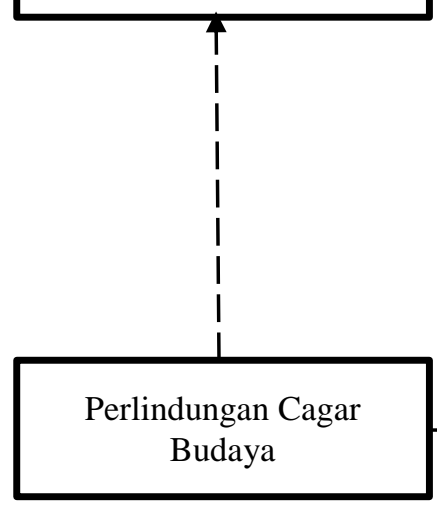

Volume 7 Nomor 1 - April 2018 - pISSN 2301-878X - e ISSN 2541- 2973

Gambar 1. Perlindungan Cagar Budaya

Sumber: Balai Pelestarian Cagar Budaya, 2016
Darurat, Kerusakan, Pemindahan, Terancam.

Agar tidak hilang, rusak, hancur, musnah, pemilik, juru pelihara, polusi, masyarakat

Zona inti, zona pendukung dan zona penyangga.

Perawatan: konservasi, penataan lingkungan, pemeliharaan fasilitas

Pertorasi, rekonstruksi, rehabilitasi, konsolidasi, konservasi. 
Mira Hafizhah T, Kajian Zonasi Kawasan Cagar Budaya di Kecamatan Siak Kabupaten Siak

\section{METODE PENELITIAN}

Analisis penentuan zonasi ini dilakukan untuk mendapatkan zonasi. Dalam analisis zonasi digunakan teknik analisis deliniasi. Alat analisis ini merupakan salah satu alat yang digunakan untuk mendapatkan data kualitatif. Pemilihan alat analisis ini, karena data yang berhubungan dalam penyusunan zonasi kawasan cagar budaya di Kecamatan Siak berupa data kualitatif yang akan dikonversi dengan data spasial dalam bentuk peta. Deliniasi adalah metode yang digunakan dalam analisis penentuan zonasi berdasarkan prinsip-prinsip perlindungan cagar budaya, karena input yang digunakan dalam analisis adalah peta-peta spasial dengan data-data berupa data spasial, yaitu peta citra google earth dengan menggunakan batas alam (sungai, hutan dan lembah) dan buatan manusia (jalan, selokan air, dan bendungan).

Penentuan zona inti didasarkan dari persebaran objek cagar budaya ditambah dengan batas aktivitas budaya yang ada di sekitar cagar budaya. Untuk zona pendukung didasarkan dari ketersediaan fasilitas penunjang cagar budaya. Sedangkan untuk penentuan zona penyangga didasarkan dari aktivitas masyarakat dapat dilihat dari jenis/prilaku kegiatan masyarakat di sekitar zona inti yang masih mendukung zona inti. Selain itu, juga didasarkan dari radius perlindungan zona inti itu sendiri. Untuk penentuan zona ini secara keseluruhan menggunakan batas alam (sungai, hutan dan lembah) buatan manusia (jalan, selokan air, dan bendungan). Sehingga hasil dari analisis ini akan didapatkan pembagian zonasi kawasan cagar budaya di Kecamatan Siak berupa zona inti, zona pendukung dan zona penyangga.

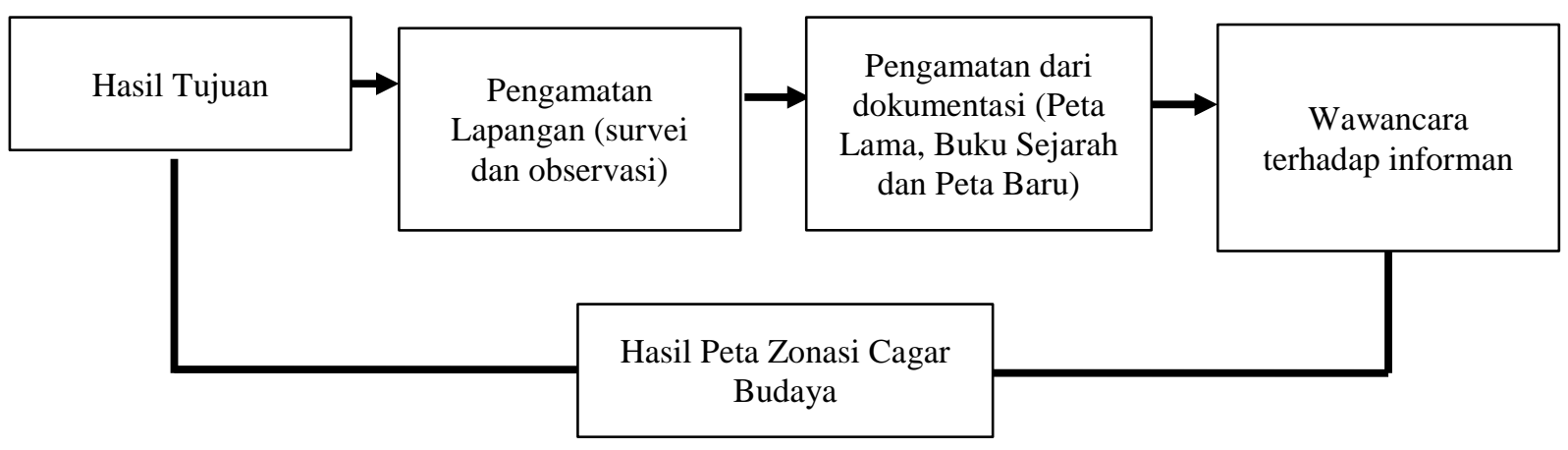

Gambar 2. Tahapan Deliniasi Zonasi Cagar Budaya Sumber: Hasil Analisis Penulis

Data yang dideskripsikan melalui stakehoder tersebut akan berbeda sesuai dengan perannya masing-masing. Untuk menentukan zonasi kawasan cagar budaya ini berpedoman Undang-Undang Nomor 11 Tahun 2010 telah disebutkan bahwa, pelindungan terhadap cagar budaya salah satunya dapat dilakukan melalui penyusunan zonasi, sehingga data yang akan diidentifikasi pada masing-masing stakeholder adalah yang terkait dengan perlindungan kawasan cagar budaya di 
Kecamatan Siak. Untuk lebih jelasnya dapat dilihat pada Gambar dibawah ini mengenai tahapan untuk menentukan deliniasi zonasi cagar budaya.

\section{HASIL DAN PEMBAHASAN}

Untuk menentukan zonasi kawasan cagar budaya di Kecamatan Siak, ketiga variabel inilah yang kemudian dijadikan prinsip perlindungan kawasan cagar budaya. Persebaran objek cagar budaya juga merupakan faktor penting yang perlu diperhatikan dalam menyusun zonasi karena sangat berpengaruh dalam penentuan zona inti. Persebaran komponen/objek cagar budaya di Kecamatan Siak ini akan menentukan karena dengan mengetahui bagaimana persebarannya akan diketahui bagaimana pola zonasinya, apakah bentuk sel, kelompok atau gabungan. Dengan demikian proses analisis deliniasi untuk masing-masing variabel dapat dilihat pada Tabel dibawah ini:

Tabel 2. Batas zonasi cagara budaya

\begin{tabular}{|c|c|c|c|}
\hline Zonasi & Indikator & Batas Zonasi & Penentuan Batas \\
\hline Zona Inti & Batas budaya & $\begin{array}{c}\text { Persebaran situs cagar } \\
\text { budaya dan aktivitas } \\
\text { budaya }\end{array}$ & \multirow{3}{*}{$\begin{array}{c}\text { Batas Alam (sungai, } \\
\text { hutan dan lembah) } \\
\text { Buatan Manusia } \\
\text { (jalan, selokan air, } \\
\text { dan bendungan) }\end{array}$} \\
\hline Zona Pendukung & $\begin{array}{l}\text { Fasilitas pendukung cagar } \\
\text { budaya }\end{array}$ & $\begin{array}{c}\text { Ketersediaan Fasilitas } \\
\text { Pendukung Cagar } \\
\text { Budaya }\end{array}$ & \\
\hline Zona Penyangga & Aktivitas masyarakat & $\begin{array}{c}\text { Jenis/Perilaku kegiatan } \\
\text { masyarakat }\end{array}$ & \\
\hline
\end{tabular}

Sumber: Ardhan et al. (2014)

Sesuai ketentuan dalam Undang-Undang Nomor 11 Tahun 2010 tentang Cagar Budaya penentuan zona dilakukan berdasarkan hasil kajian. Karena itu, dalam rangka penentuan zonasi dilakukan kajian terhadap berbagai informasi yang dapat diperoleh terkait dengan cagar budaya tersebut. Sumber-sumber informasi yang digunakan dalam kajian ini adalah peta lama, sumber kepustakaan (buku refrensi sejarah), sumber sejarah lokal, laporan penelitian, peta baru untuk kondisi terkini (existing condition), dan hasil pengamatan langsung di lapangan dan wawancara kepada stakeholder. Untuk lebih jelasnya lihat gambar 3.

Zonasi Cagar Budaya menjadi langkah yang strategis untuk memberikan perlindungan secara langsung terhadap cagar budaya maupun lingkungannya. Menelusuri fakta dilapangan saat ini memperlihatkan bahwa kawasan cagar budaya di Kecamatan Siak belum memiliki zonasi, padahal disatu sisi cagar budaya memiliki nilai penting sekaligus tingkat keterancaman yang tinggi. Analisis deliniasi ini dilakukan untuk menentukan zonasi kawasan cagar budaya di Kecamatan Siak, hal ini sangat perlu dilakukan sebagai langkah antisipasi maupun upaya meminimalisir kesalahan penanganan dan pengelolaan kedepan. 
Pada penelitian ini untuk cagar budaya yang dijadikan satu kelompok zona inti adalah Bangunan Balai Kerapatan Tinggi, Makam Sultan Syarif Kasim II, Masjid Raya Siak Syahbuddin, Istana Siak, Jembatan Istana Siak, Makam Koto Tinggi dan Gudang Mesiu selain karena letaknya yang berdekatan ketujuh bangunan cagar budaya ini juga memiliki hubungan sejarah yang sama yaitu merupakan komplek Istana Siak yang dulunya merupakan tempat sultan Siak melaksanakan aktivitas pemerintahan kerajaan. Pada analisis Peta Lama diketahui tahun 1898 Sultan merancang pemerintahan kerajaan dengan membangun Istana Siak menjadi tempat tinggal Sultan, Balai Kerapatan Tinggi merupakan kantor Sultan sekaligus ruang pertemua untuk melakukan sidang dan pertemuan kerajaan. Sultan juga membangun Masjid Raya Syahbuddin sebagai tempat beribadah dan merayakan hari besar islam. Pada kondisi sekarang keberadaan bangunan cagar budaya masih terawat dan morfologi Kota Siak tahun 1898 masih bertahan hingga saat ini dapat dilihat dari keberadaan jalan yang menjadi identitas kota yaitu Jalan Sultan Syarif Kasim yang terdapat di depan istana dan Jalan Sultan Ismail yang terdapat di depan Balai Kerapatan Tinggi hingga depan Kelenteng Hok Sing Kong serta keberadaan Sungai Siak yang juga menjadi identitas dari Kota Siak. Sehingga dengan menggunakan jalan dan sungai tersebut dapat digunakan sebagai batas deliniasi untuk zona inti, zona pendukung dan zona penyangga cagar budaya di Kecamatan Siak.

Untuk membantu merekam berbagai faktor yang memberikan pengaruh dalam menentukan kebijakan tata ruang lahan. Untuk melengkapi kegiatan tersebut, maka langkah yang terakhir adalah mengadakan wawancara kepada stakeholder yang terdiri dari Dinas Pekerjaan Umum, BAPPEDA, PU TARUKIM, Dinas Pariwisata, Dinas Pendidikan dan Kebudayaan, Anggota Dewan, Camat, Lurah, Ketua PKK, Ketua Persatuan Minang Kabau, Ketua Persatuan Jawa, Ketua Persatuan Melayu dan Ketua Pemuda yang dianggap mengetahui berbagai hal tentang seluk-beluk objek tersebut serta keadaan lingkungan sekitarnya. Penggambaran dan pemetaan dilakukan dengan mengadakan plotting dengan menggunakan AutoCAD 2016 merupakan salah satu alat (tools) yang bisa digunakan untuk analisis deliniasi. Seperti telah dijelaskan sebelumnya, analisis deliniasi dilakukan dengan menggunakan tiga variabel dari prinsip perlindungan arkeologi terhadap komponen/objek cagar budaya. Penentuan zona inti didasarkan dari persebaran objek cagar budaya ditambah dengan batas aktivitas budaya yang ada di sekitar cagar budaya. Untuk zona pendukung didasarkan dari ketersediaan fasilitas penunjang cagar budaya. Sedangkan untuk penentuan zonasi penyangga didasarkan dari aktivitas masyarakat dapat dilihat dari jenis/prilaku kegiatan masyarakat di sekitar zona inti yang masih mendukung zona inti. Selain itu, juga didasarkan dari radius perlindungan zona inti itu sendiri. Untuk penentuan zona ini secara keseluruhan menggunakan batas alam (sungai, hutan dan lembah) buatan manusia (jalan, selokan air, dan bendungan). 
Mira Hafizhah T, Kajian Zonasi Kawasan Cagar Budaya di Kecamatan Siak Kabupaten Siak

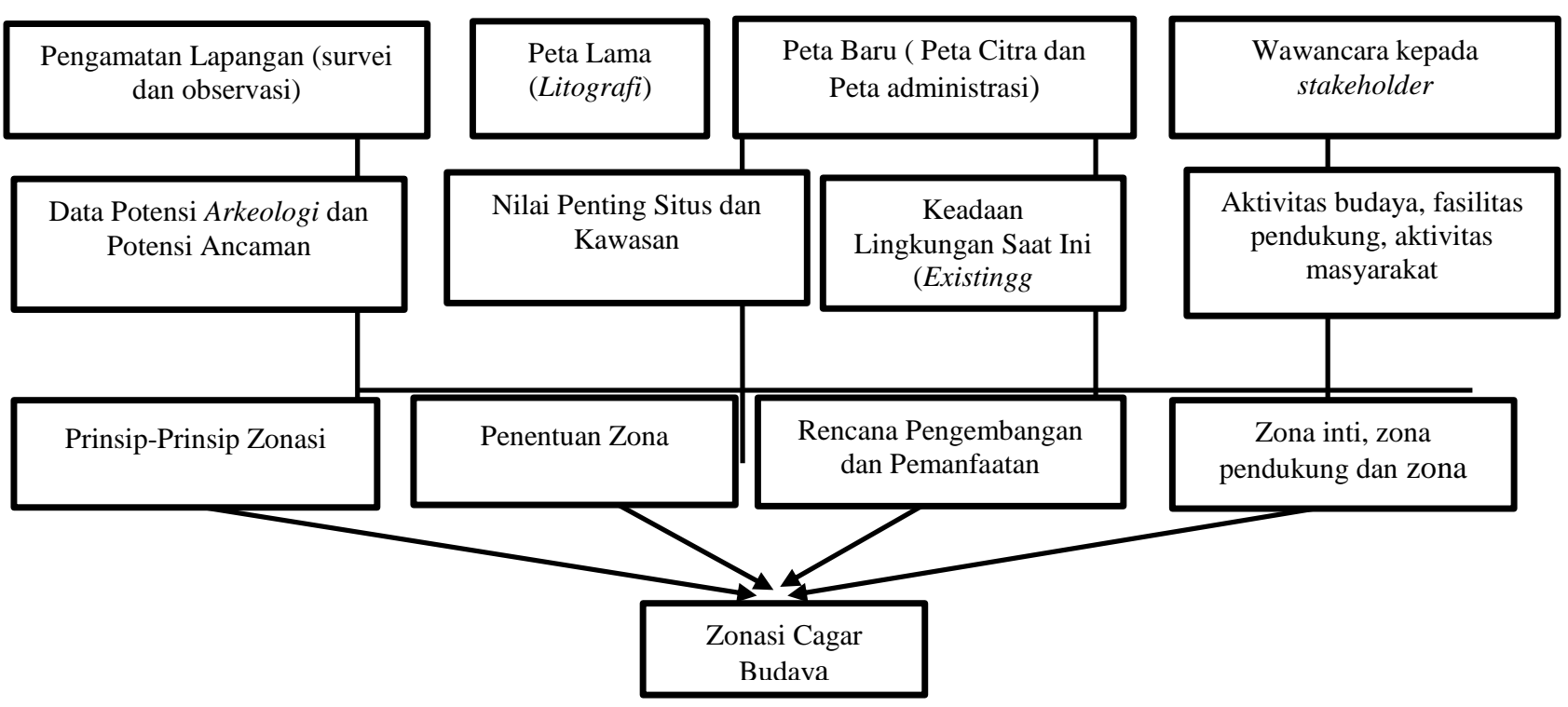

Gambar 3. Metodelogi Zonasi Situs dan Kawasan Cagar Budaya

Sumber: Laporan Zonasi Benteng Somba Opu, yang dimodifikasi sesuai dengan kebutuhan)

\section{Zona Inti Cagar Budaya di Kecamatan Siak}

Zonasi kawasan utama cagar budaya di Kecamatan Siak terbagi menjadi tiga yaitu zona inti, zona pendukung dan zona penyangga. Zona inti adalah zona komponen/objek bangunan cagar budaya yang terdiri dari luas bangunan ditambah dengan aktivitas budaya dan dapat berupa beberapa (kelompok) objek bangunan cagar budaya. Sehingga dengan demikian bentuk zona inti adalah gabungan antara kelompok dan sel.

\section{a. Deliniasi Zona Inti Kompleks Kerajaan Siak}

Berdasarkan arkeologi, sejarah, letak sebaran cagar budaya yang berdekatan, pengamatan di lapangan serta diskusi yang dilakukan bersama stakeholder zona inti khusus meliputi area Balai Kerapatan Tinggi, Makam Sultan Syarif Kasim II, Masjid Raya Siak Syahbuddin, Istana Siak, Jembatan Istana Siak, Makam Koto Tinggi dan Gudang Mesiu disatukan dalam satu zona inti, meski dalam data base Balai Pelestarian Cagar Budaya Sumatra Barat dipisahkan menjadi tujuh nomor inventaris. Alasan penyatuannya adalah berdasarkan batas asli menunjukkan satu kesatuan kompleks dari Istana Siak dimana Istana Siak Sri Indrapura merupakan tempat kediaman atau istana raja-raja Siak Sri Indrapura dan tempat menerima tamu-tamu kenegaraan, kemudian di sisi barat dari istana terdapat Balai Kerapatan Tinggi yang memegang fungsi penting dalam aktivitas pemerintahan. Selain sebagai kantor Sultan, Balai Kerapatan Tinggi berfungsi untuk tempat Sultan bermusyawarah dan pertemuan (sidang) Sultan dengan panglima-panglimanya dan juga berfungsi sebagai tempat Sultan menemui tamu 
Mira Hafizhah T, Kajian Zonasi Kawasan Cagar Budaya di Kecamatan Siak Kabupaten Siak

istana, pejabat-pejabat serta rakyat hamba negerinya. Masjid Raya Siak Syahbuddin merupakan tempat beribadah Sultan dan tempat kegiatan keagamaan Sultan. Karena tanah disamping masjid masih merupakan tanah milik kerajaan setelah meninggal Sultan Syarif Kasim II di Rumbai (Pekanbaru) jenazah beliau kemudian dimakamkan dibelakang Masjid Sultan (Masjid Syahabuddin) di Kota Siak kemudian juga istri Sultan pertama Tengku Agung Sultanah Latifah serta istri Sultan yang keempat. Tidak kalah penting juga keberadaan Jembatan Istana yang terletak di sisi kiri dari istana memiliki nilai sejarah yang penting yaitu Jembatan Istana merupakan sarana penghubung ke luar istana dengan masyarakat lingkungan istana yang bernama Jembatan Suka Ramai.Gudang Mesiu yang terdapat pada sisi timur dari Istana Siak menurut ketua Lembaga Adat Melayu Siak Gudang Mesiu merupakan peninggalan belanda yang diambil alih oleh Kerajaan Siak dan digunakan untuk menyimpan senjata dan bahan bakar meriam kerajaan. Komplek makam koto tinggi merupakan makam Sultan Assyadissrafif Ibrahim Abdul Jalil Khaliluddin dan Sultan Assaidissrif Kasim Syaifuddin Marhum atau Sultan Kasim I yang merupakan makam tokoh utama Kerajaan Siak yaitu Sultan Kasim I. Maka dari itu untuk zona inti Kerajaan Siak meliputi Balai Kerapatan Tinggi, Makam Sultan Syarif Kasim II, Masjid Raya Siak Syahbuddin, Istana Siak, Jembatan Istana Siak, Makam Koto Tinggi dan Gudang Mesiu dengan menggunakan sistem zonasi kelompok atau blok. Untuk zona inti Kerajaan Siak memiliki luas lahan sebesar 9,56 Ha, aktivitas budaya yang ada di zona inti Kerajaan Siak berupa kegiatan Kerajaan Siak seperti upacara Kerajaan yang berada tepat di depan istana, Acara Siak Bermada, Acara Pawai Budaya, Lomba Zapin Internasional, Ghatib Beghanyut, Silat Sijori.

\section{b. Zona Inti Kelenteng Hok Sing Kong}

Berdasarkan arkeologi, sejarah, letak cagar budaya, pengamatan di lapangan serta diskusi yang dilakukan bersama stakeholder zona inti Kelenteng Hok Sing Kong di deliniasi satu blok saja, karena letaknya cukup berjauhan dari Kompleks Istana sehingga sistem zonasinya menggunakan sistem sel. Kelenteng Hok Sing Kong merupakan pusat peribadatan bagi masyarakat etnis Tionghoa yang terdiri dari bangunan bersejarah berupa kelenteng ini dibangun pada tahun 1871 sebagaimana tanggal yang tertera diatas pintu masuk kelenteng, angka tahun ini menunjukkan bahwa kelenteng ini dibangun pada masa pemerintahan Sultan Assyaidis Syarif Kasim Abduljalil Syaifuddin (Sultan Syarif Kasim I) yang memerintah pada tahun 1864-1889. Selain itu pertimbangan lainnya adalah Kelenteng merupakan peninggalan etnis Tionghoa pada masa lalu dan tentunya berbeda budaya dengan zona Kompleks Kerajaan Siak. Aktivitas budaya masih dilakukan dalam kawasan kelenteng dengan luas sebesar 0,32 Ha. Aktivitas budaya yang dilakukan di Kelenteng Hok Sing Kong ini berupa perayaan imlek, pertunjukan capgome yang merupakan perayaan untuk para dewa, diselenggarakan juga pawai barongsai, naga, kembang api, acara pertunjukan 
kerasukan dewa dan makan malam bersama yang diselenggarakan masih dalam plataran kawasan bangunan Kelenteng Hok Sing Kong.

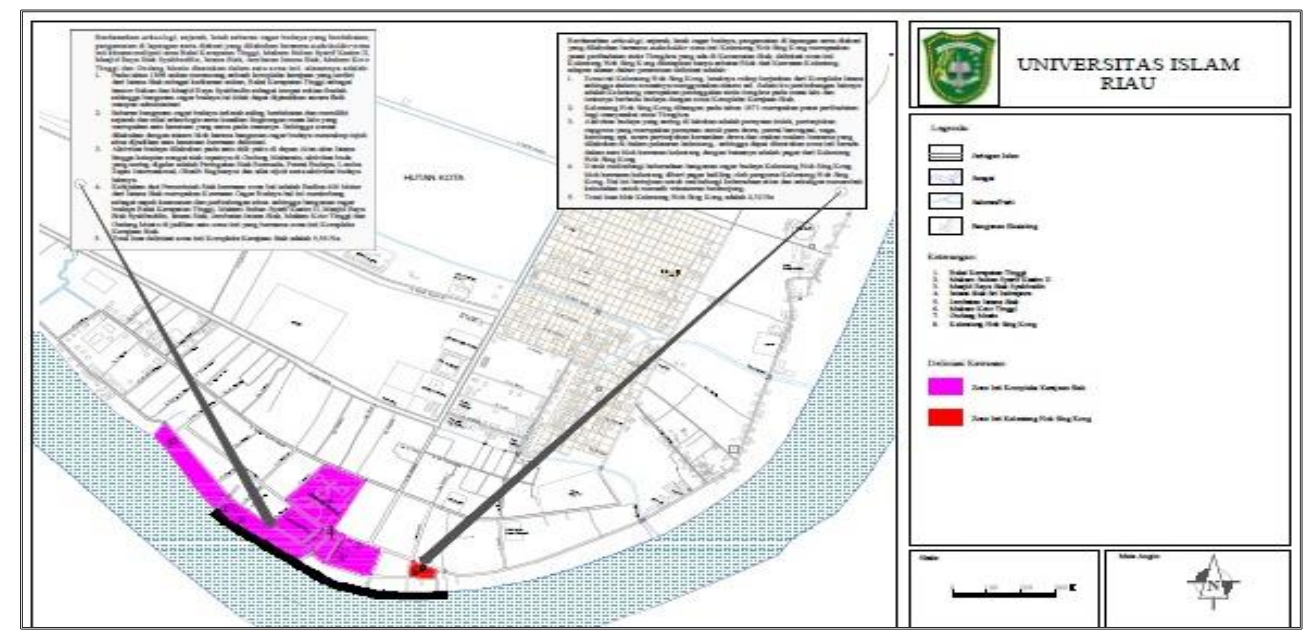

Gambar 4. Peta Analisis Deliniasi Zona Inti Cagar Budaya di Kecamatan Siak

\section{Zona Pendukung Cagar Budaya di Kecamatan Siak}

Selanjutnya ialah penentuan zona pendukung dari masing-masing zona inti di atas. Zona pendukung adalah kawasan diluar zona inti. Fungsi utama zona pendukung adalah sebagai pendukung dari zona inti. Dalam menentukan zona pendukung ini berdasarkan ketersediaan fasilitas penunjang yang mendukung zona inti sama halnya dengan zona inti, zona pendukung ini terdiri dua zona pendukung untuk setiap zona inti.

\section{a. Deliniasi Zona Pendukung Kompleks Kerajaan Siak}

Zona pendukung Kompleks Kerajaan Siak terletak pada bagian sebelah barat, timur dan utara Istana Siak. Zona pendukung Kompleks Kerajaan Siak di sebelah barat merupakan kompleks permukiman masyarakat melayu dilihat dari atab rumahnya berarsitektur melayu yang bernama gajah minum, untuk sebelah timur merupakan kawasan komersil yaitu pasar kesenian yang menjual berbagai oleh-oleh asli Siak seperti songket, tanjak, kuliner khas Siak dan pernak-pernik kerajinan masyarakat lokal. Sedangkan untuk zona pendukung Kompleks Kerajaan Siak yang berada bagian utara Istana Siak adalah permukiman Kerabat Kerajaan yang masih ada hingga saat ini ditandai juga dengan permukiman melayu terlihat dari arsitektur rumah panggung dan selambayung atab yang bercirikan melayu, total luas area zona pendukung Kompleks Kerajaan Siak adalah 29,72 Ha.

\section{b. Deliniasi Zona Pendukung Kelenteng Hok Sing Kong}

Zona pendukung Kelenteng Hok Sing Kong ini terletak di koridor Jalan Sultan Ismail. Zona pendukung Kelenteng Hok Sing Kong ini merupakan Pecinan yang merupakan pasar lama yang menjadi pusat pertokoan yang menjual 
pernak pernik untuk perayaan hari besar masyarakat Tionghoa seperti lampion, kue bulan, manisan Cina dan peralatan upacara lainnya. Total luas area zona pendukung Kelenteng Hok Sing Kong adalah 2,74 Ha.

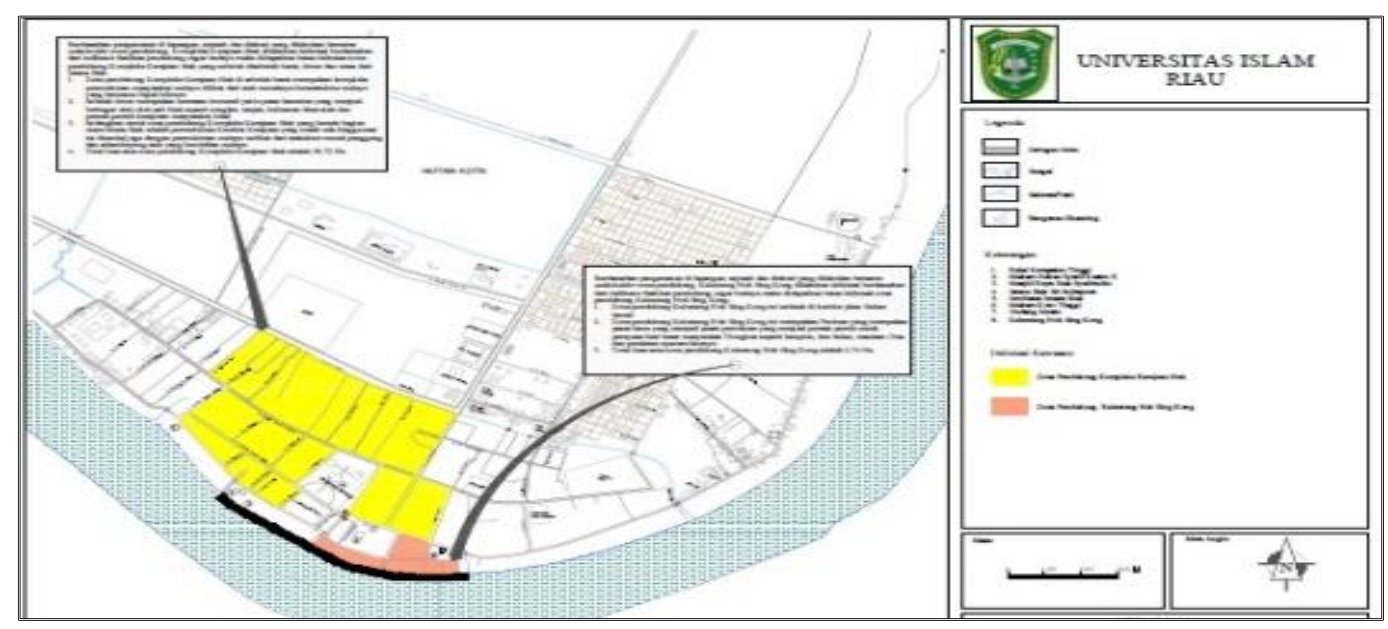

Gambar 5. Peta Analisis Deliniasi Zona Pendukung Cagar Budaya di Kecamatan Siak

\section{Zona Penyangga Cagar Budaya di Kecamatan Siak}

Sedangkan zona penyangga adalah kawasan diluar zona inti dan pendukung dimana kawasan ini berfungsi sebagai pelindung. Selain itu juga dalam menentukan zona penyangga ini berdasarkan aktivitas atau jenis kegiatan masyarakat yang mendukung zona inti dan pendukung, zona penyangga ini terdiri dari dua zona penyangga untuk setiap zona inti.

a. Deliniasi Zona Penyangga Kompleks Kerajaan Siak

Zona penyangga Kompleks Kerajaan Siak ini terletak di kawasan permukiman jenis/aktivitas masyarakat dimana pada zona ini tedapat kegiatan indusri kerajinan tanjak, dan tenun Siak yang dijual di pasar seni dan di kirim ke luar Siak. Kemudian juga terdapat taman suak santai sebagai ruang terbuka dan digunakan masyarakat sebagai aktivitas olah raga dan bersantai di pinggir sungai. Taman ini terdapat dekat bibir sungai dan merupakan ruang terbuka hijau (RTH) mangrove yang juga berfungsi sebagai penyangga sungai menahan abrasi dari air sungai. Total luas area zona penyangga adalah 17,52 $\mathrm{Ha}$.

\section{b. Deliniasi Zona Penyangga Kelenteng Hok Sing Kong}

Zona penyangga Kelenteng Hok Sing Kong ini terletak di Jalan Sultan Syarif Kasim zona ini memiliki jenis/kegiatan masyarakat yaitu kegiatan berdagang pada kawasan ini juga terdapat pemakaman etnis tionghoa yang menandakan kawasan ini didominasi oleh etnis tionghoa. Kemudian juga pada kawasan ini terdapat ruang terbuka disepanjang pinggiran sungai yang berfungsi 
sebagai penyangga dari abrasi. Total luas area zona penyangga Kelenteng Hok Sing Kong adalah 33,38 Ha

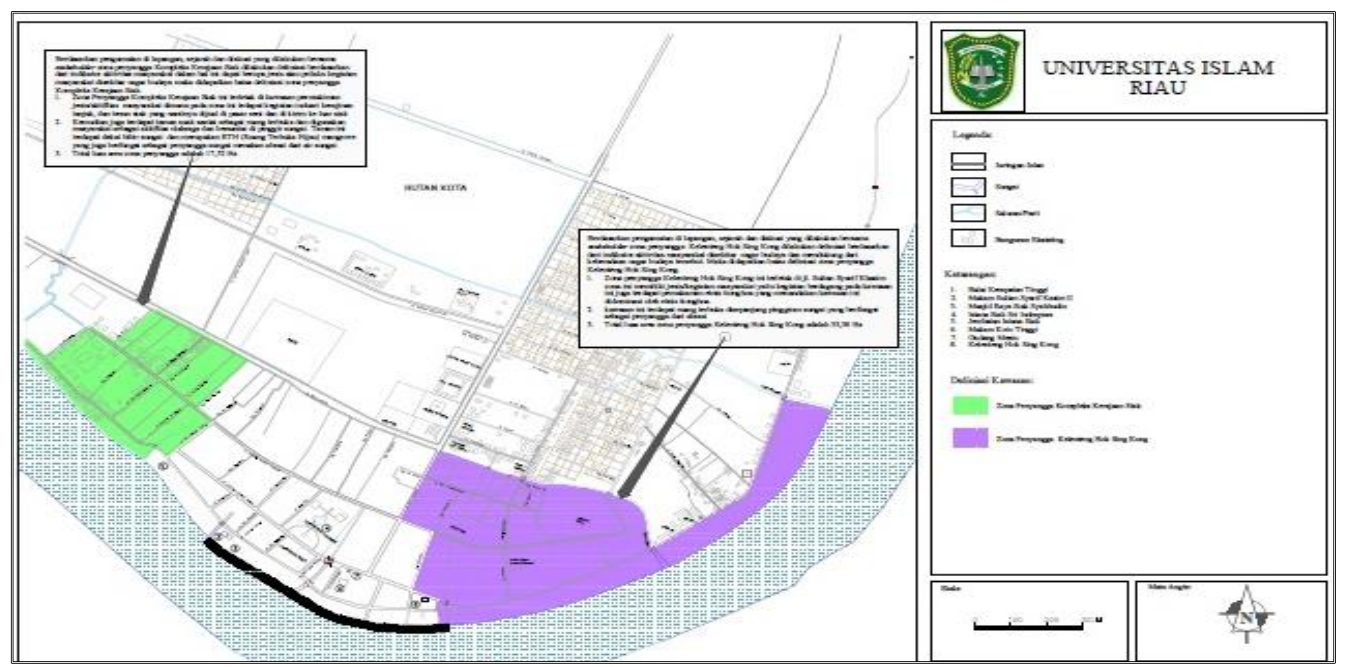

Gambar 6. Peta Analisis Deliniasi Zona Penyangga Cagar Budaya di Kecamatan Siak

\section{E. KESIMPULAN}

Setelah mengetahui delapan situs cagar budaya yang terdapat di Kecamatan Siak selanjutnya ditentukan zonasi yang terdiri dari zona inti, zona pendukung dan zona penyangga. Berdasarkan arkeologi, sejarah, letak sebaran cagar budaya yang berdekatan, pengamatan di lapangan serta diskusi yang dilakukan bersama stakeholder zona inti ini terdiri dari dua zona inti yang mana zona inti pertama adalh zona inti Kompleks Kerajaan Siak terdiri dari Balai Kerapatan Tinggi, Makam Sultan Syarif Kasim II, Masjid Raya Siak Syahbuddin, Istana Siak, Jembatan Istana Siak, Makam Koto Tinggi dan Gudang Mesiu. Zona inti kedua adalah Zona Inti Kelenteng Hok Sing Kong. Sedangkan untuk zona pendukung adalah lahan diluar zona inti yang berfungsi sebagai pendukung situs atau objek bangunan cagar budaya. Adapun zona pendukung dari zona pendukung Kompleks Kerajaan Siak di sebelah barat merupakan kompleks permukiman masyarakat melayu dilihat dari atab rumahnya berarsitektur melayu yang bernama gajah minum, untuk sebelah timur merupakan kawasan komersil yaitu pasar kesenian yang menjual berbagai oleh-oleh asli Siak seperti songket, tanjak, kuliner khas Siak dan pernak-pernik kerajinan masyarakat lokal. Zona pendukung Kompleks Kerajaan Siak yang berada bagian utara Istana Siak adalah permukiman Kerabat Kerajaan yang masih ada hingga saat ini ditandai juga dengan permukiman melayu terlihat dari arsitektur rumah panggung dan selambayung atab yang bercirikan melayu. untuk zona pendukung Kelenteng Hok Sing Kong ini merupakan Pecinan yang merupakan pasar lama yang menjadi pusat pertokoan yang menjual pernak pernik untuk perayaan hari besar masyarakat Tionghoa seperti lampion, kue bulan, manisan Cina dan peralatan upacara lainnya. 
Mira Hafizhah T, Kajian Zonasi Kawasan Cagar Budaya di Kecamatan Siak Kabupaten Siak

Zona penyangga merupakan lahan diluar zona inti dan pendukung yang masih memiliki pengaruh dari kegiatan atau aktivitas masyarakat. Untuk zona penyangga Kompleks Kerajaan Siak ini terletak di kawasan permukiman jenis/aktivitas masyarakat dimana pada zona ini tedapat kegiatan indusri kerajinan tanjak, dan tenun Siak yang dijual di pasar seni dan di kirim ke luar Siak. Kemudian juga terdapat taman suak santai sebagai ruang terbuka dan digunakan masyarakat sebagai aktivitas olah raga dan bersantai di pinggir sungai. Taman ini terdapat dekat bibir sungai dan merupakan ruang terbuka hijau (RTH) mangrove yang juga berfungsi sebagai penyangga sungai menahan abrasi dari air sungai. Zona penyangga Kelenteng Hok Sing Kong ini terletak di Jalan Sultan Syarif Kasim zona ini memiliki jenis/kegiatan masyarakat yaitu kegiatan berdagang pada kawasan ini juga terdapat pemakaman etnis Tionghoa yang menandakan kawasan ini didominasi oleh etnis Tionghoa. Kemudian juga pada kawasan ini terdapat ruang terbuka disepanjang pinggiran sungai yang berfungsi sebagai penyangga dari abrasi.

\section{DAFTAR PUSTAKA}

Ardhan, Taufiq. 2014. Arahan Pengembangan Kota Palembang Sebagai Kota Pusaka. Surabaya. Surabaya: Institut Teknologi Sepuluh November

Aristian, Febry. 2012. Urgensi Pengaturan Zona Dalam Upaya Pengendalian Pemanfaatan Ruang Daerah Berkelanjutan. Diakses dari http://febryaristian.blogspot.co.id/2011/10/urgensi-pengaturan-zona-dalamupaya_21.html?m=1 pada 8 Maret 2017 pukul 20.23 WIB

Derektorat Pelestarian Cagar Budaya Dan Permuseuman, Direktorat Jendral Kebudayaan Republik Indonesia. 2015. Diakses dari http://kebudayaan.kemdikbud.go.id/ditpcbm/2015/10/28/seputar-

pemanfaatan-cagar-budaya-yang-harus-diketahui/ pada 8 Maret 2017 pukul 20.23 WIB

Mulyadi, Yadi. 2012. Mengoptimalkan Zonasi Sebagai Upaya Pelestarian Cagar Budaya. Buletin Somba Opu Balai Pelestarian Peninggalan Purbakala Makassar Vol 15 No. 19 September 2012

Undang-Undang Nomor 11 Tahun 2010 tentang Cagar Budaya. 